
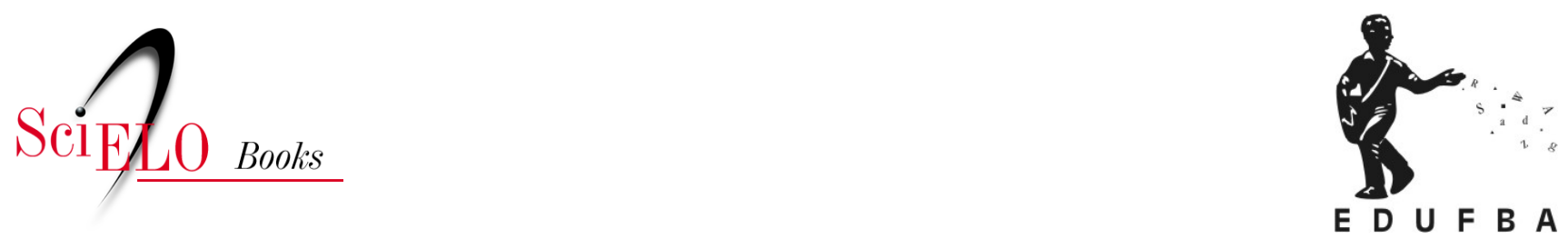

\title{
Destinos e escolhas \\ a classe média escolarizada no candomblé
}

\author{
Luciana Duccini
}

DUCCINI, L. Destinos e escolhas: a classe média escolarizada no candomblé. In: Diplomas e decá: identificação religiosa de membros de classe média no candomblé [online]. Salvador: EDUFBA, 2016, pp. 95-143. ISBN 978-85-232-2011-2. https://doi.org/10.7476/9788523220112.0005.

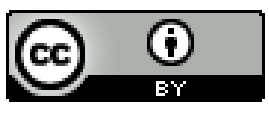

All the contents of this work, except where otherwise noted, is licensed under a Creative Commons Attribution 4.0 International license.

Todo o conteúdo deste trabalho, exceto quando houver ressalva, é publicado sob a licença Creative Commons Atribição $\underline{4.0}$.

Todo el contenido de esta obra, excepto donde se indique lo contrario, está bajo licencia de la licencia Creative Commons Reconocimento 4.0 . 


\title{
Destinos e escolhas: a classe média escolarizada no candomblé
}

\begin{abstract}
Porque a principal mudança, ela é interior, né? A partir da minha mudança interior, a minha mudança de valores, que eu acho que a principal [...] a mudança de condição, financeira e tal, isso é mínimo. Não, cê pode estar muito bem como protestante, como católico, não importa, não é isso. A questão financeira, social, é uma outra história, mas a principal mudança, ela é interior. A forma como você vê a vida, a forma como você busca orientar e conduzir a tua vida, e as pessoas que te buscam. Que tipo de orientação você pode dar, né? (Robson, babalorixá)
\end{abstract}

Nesta fala de pai Robson, podemos identificar duas noções muito comuns em nossa sociedade: a de que todos nós temos uma espécie de "vida interior" e a de que esta vida interior pode ser transformada, ganhar outras “orientações”, mesmo sem mudanças visíveis nas condições sociais da pessoa. Em termos familiares ao senso comum acadêmico, poderíamos dizer que, para pai Robson, podemos sofrer (e até buscar ativamente) modificações subjetivas sem que estas correspondam a mudanças objetivas em nossas vidas e relações. Para muitos ainda, como Giddens (2002), é na capacidade de nos voltar- 
mos reflexivamente para esse aspecto subjetivo que reside a particularidade da construção de identidades na modernidade:

Começamos com a premissa de que ser humano é saber, quase sempre, em termos de uma descrição ou outra, tanto o que se está fazendo como por que se está fazendo. [...] As convenções sociais produzidas e reproduzidas em nossas atividades diárias são refleximamente monitoradas pelo agente como parte do "seguir em frente" nas diversas situações de nossas vidas. A consciência reflexiva nesse sentido é característica de toda ação humana, e é a condição específica daquela reflexividade instituicional maciçamente desenvolvida, [...] como componente intrínseco da modernidade. (GIDDENS, 2002, p. 39)

Uma vez que a questão central deste trabalho é "como pessoas de classe média passam a se identificar com o candomblé”, a proposição de Giddens sobre processos reflexivos na formação de autoidentidades na contemporaneidade desperta interesse. Afinal, como o autor argumenta, as próprias instituições sociais em que agimos, hoje em dia, são marcadas por alto grau de revisão e incorporação reflexivas de suas ações. Poderíamos dizer, em termos weberianos, que a própria noção de modernidade ficou marcada pelo desenvolvimento, cada vez mais acentuado, de racionalizações em variadas esferas de ação (WEBER, 1974c, 2006), incluindo as concepções de identidade e pessoa, apresentando, portanto, fortes afinidades com o desenvolvimento de religiosidades interiorizadas, isto é, centradas na autoinspeção sistemática do próprio comportamento e consciência, muito mais do que em fórmulas mágicas ou rituais. (WEBER, 2004, p. 105-107) Contudo, uma vez que não se deve partir de significações já prontas, seja a ideia de "identidade" ou a de "modernidade", é necessário considerar, ainda que brevemente, como tais noções vieram a se tornar correntes para nós, tanto no meio acadêmico quanto no leigo. Assim, a seguir será apresentada uma tentativa de análise do candomblé como religião em uma sociedade "moderna" - destacando os possíveis "atrativos" que oferece a seus adeptos e, posteriormente, uma interpretação da formação de identidades de 
pessoas de classe média nesse contexto. É evidente que a seleção dos autores escolhidos para sustentar a argumentação já indica filiação a suas ideias, mesmo não sendo uma incorporação de todos os seus aspectos. Portanto, a seguir não será apresentada uma revisão da literatura sobre modernidade ou identidade, mas sim uma apropriação teórica que considero adequada aos objetos desta pesquisa.

Como ponto de partida, gostaria de remeter às análises de Max Weber sobre as inter-relações entre o processo histórico de desenvolvimento da sociedade ocidental moderna e o das religiões nela existentes. Um dos aspectos trabalhados pelo autor, e central nesta discussão, refere-se à importância de certas camadas sociais, no papel de grupo preferencial de adeptos, para a gestação de formas específicas de religiosidade. (WEBER, 1974a, 1974b) A religião deve atender aos interesses - sejam eles "materiais" e/ou "ideais" - de seus fiéis, interesses que estão relacionados ao estilo de vida do grupo social a que pertencem. Assim, nas sucessivas gerações dos membros de uma comunidade religiosa, a religião vai tomando as feições que melhor respondem aos interesses da camada social que mais the fornece participantes. Esta relação, porém, não é unívoca e, segundo o autor, “[...] o tipo de uma religião, uma vez marcado, exerceu habitualmente uma influência de amplas consequências sobre o modo de vida de camadas muito heterogêneas". (WEBER, 1974a, p. 312) Ou seja, se a posição social dos adeptos preferenciais pode marcar profundamente o estilo de uma forma religiosa, esta também pode influenciar a condução da vida em grupos muitos variados. Dessa forma, a própria concepção corrente de "vida interior" reflexivamente monitorada pelo sujeito - acima referida à Giddens - poder ter seu parentesco remetido aos desenvolvimentos do protestantismo dos séculos XVI e XVII, sobretudo às seitas puritanas com sua ênfase na necessidade de condução metódica e racionalizada de todas as ações cotidianas mundanas, em oposição a qualquer possibilidade de salvação por ações exteriores. (WEBER, 2004, p. 105-107) ${ }^{48}$

48 E especialmente. (WEBER, 2004, p. 131-138) 
Contudo, a própria identificação de uma camada social preferencialmente fornecedora dos membros de uma religião particular é uma tarefa bastante complicada, pois se dá de forma retrospectiva, isto é, como historicamente ocorreu em casos particulares, uma vez que não há uma relação necessária nem exclusiva que permitiria a previsão das eleições religiosas pessoais ou coletivas. Em outras palavras, não há nas religiões em si, tampouco nas posições sociais, elementos intrínsecos que determinem umas para camadas superiores e outras para inferiores. O mesmo pode ser afirmado acerca da possibilidade de uma camada social - seja ela urbana, rural, guerreira ou comercial - vir a influenciar de modo decisivo o comportamento econômico de toda uma sociedade num dado momento histórico, mesmo perdendo esta preeminência em outros períodos. (WEBER, 1974b, 1974c, 1991, 1996)

As análises de Roger Bastide sobre a formação do candomblé e suas variações já apresentavam afinidades entre esta religião e particularidades da sociedade brasileira, conjugando uma "[...] sociologia dos contatos de civilizações, tal como se processaram entre nós [e] uma antropologia africana que ele pretende esboçar a partir do exame dos universos africanos aqui existentes”. (PEIXOTO, 2000, p. 95) Ao analisar o sincretismo brasileiro entre catolicismo e religiões africanas, Bastide defende a pertinência de três princípios lógicos: de participação, segundo o qual elementos distintos são pensados como essencialmente aparentados; de corte, que permite a divisão das esferas de ação em "universos" simbólicos apartados; e de correspondência, subjacente às operações de analogia entre elementos de diferentes "universos", sem que estes "participem" conjuntamente de um mesmo nível da realidade. (PEIXOTO, 2000. p. 110) Dessa forma, "participações" ocorreriam entre "universos" de conhecimento/pensamento, mas entre estes e o universo da inserção social ocorreriam analogias, permitindo que os negros brasileiros transitassem entre distintas esferas e, ao mesmo tem- 
po, mantivessem certos traços de suas culturas africanas originais. (PEIXOTO, 2000. p. 112)

Embora a complexa combinação desses princípios permita a aceitação de brancos no universo religioso afro-brasileiro, esta se daria de modo individualizado, enquanto que a produção coletiva dos quadros simbólicos dessas religiões permaneceria negra por excelência. Durante décadas apoiada em análises da "diferença negra", pode-se dizer que, na literatura acadêmica sobre a formação do candomblé como religião, embora com ênfases muito variadas, houve uma identificação com a população mais escura e pobre das nascentes cidades brasileiras, como em Carneiro (1991) e Bastide (1971, 2001), em especial, em certa região:

Como esclarecem os trabalhos de Dantas (1988) e de Birman (1985), a construção de um discurso de 'pureza nagô' produziu um regionalismo que opunha Nordeste e Sudeste em torno do grau de preservação das origens africanas, ficando a última em situação de desvantagem tanto pela menor homogeneidade em termos de influências raciais, quanto pelo predomínio dos grupos 'bantos', cuja cultura e religiosidade não eram tão 'evoluídas' (portanto, mais vulneráveis ao 'incretismo') quanto a dos 'nagôs' que teriam povoado maciçamente o Nordeste. (apud GUIMBELLI, 2003, p. 259)

Em resumo, pode-se dizer que, durante décadas, análises socioantropológicas sobre o candomblé identificaram seus participantes como sendo tipicamente provenientes das camadas menos favorecidas em termos econômicos e educacionais, de pele mais escura, com origens africanas e residentes nas (se não natural das) cidades nordestinas. Contudo, autores como Prandi (1991, 1999) e Oro (1998) observam que, cada vez mais, indivíduos escolarizados de variadas origens religiosas e familiares vêm aderindo ao candomblé em diversas regiões do país. Essa eleição torna-se ainda mais interessante por se tratar de uma religião cuja própria "tradição" afirma sua especificidade em relação ao Ocidente: suas tão aclamadas raízes africanas e seus magníficos aspectos mágicos e rituais. Talvez o número de pes- 
soas de classe média nos terreiros não seja (ainda?) tão expressivo, mas o que chama a atenção é justamente a trajetória que os leva a se vincular a uma religião, normalmente, considerada própria de outro “extrato social”. Como, então, se dá esse processo de identificação religiosa? Que tipo de reelaboração pessoal esses indivíduos efetuam quando se envolvem com esta religião em particular? Tais questões têm ocupado posição marginal nas pesquisas socioantropológicas sobre esta religião afro-brasileira.

\section{CANDOMBLÉ, INTELECTUAIS E CAMADAS MÉDIAS NA LITERATURA ACADÊMICA}

Como dito acima, o candomblé já foi considerado como religião de um grupo social bem definido, composto por pessoas pobres e negras (PRANDI, 1999), ou como continuidade do patrimônio cultural dos africanos escravizados e seus descendentes, destacando-se a persistência da preocupação com o lugar que tais elementos ocupariam na identidade "nacional”, como apontou Birman (1997, p. 79). Mesmo que seja sempre possível uma dúvida quanto a um suposto exclusivismo racial e social dos frequentadores dos terreiros de candomblé (REIS; SILVA, 1989; SANSI, 2003), hoje esta religião é considerada "universal", isto é, aberta a todos, independente de cor ou situação socioeconômica (PRANDI, 1999, p. 93) ou "aberta a conversão de todas as pessoas”. (CAMARGO apud PIERUCCI, 2006, p. 114) Este processo de “universalização" tornou-se nítido principalmente a partir dos "anos 1960", quando na efervescência da contracultura, uma classe média "intelectualizada" passou a valorizar a "autenticidade" nacional como produto digno de atenção e consumo. (PRANDI, 1999, p. 102)

De fato, não é raro encontramos referências, na literatura acadêmica, à presença de indivíduos provenientes de camadas mais favorecidas nos grupos de culto, a começar pelos próprios pesquisadores, que desde fins do século XIX elegeram o candomblé como objeto de estudo. (DANTAS, 1988; SILVA, 1998) Entretanto, é bem 
mais difícil encontrarmos textos que deem alguma atenção analítica a esta participação. Mesmo no caso de se tratar de um pai de santo, sua escolaridade mais elevada do que o comum não parece ter chamado a atenção de Edison Carneiro (1991, p. 40), que se limita a comparar a situação de pobreza dos terreiros, cuja fisionomia não diferia "muito das casas pobres, em geral, da Bahia," com a de um templo em particular:

Segundo a concepção corrente, as mulheres devem dançar descalças sobre chão, nunca sobre soalho. Há alguns anos, Natividade [Neve Branca], pouco antes formado em odontologia, realizou uma inovação na sua casa de Brotas, pondo soalho em todos os compartimentos. Outros candomblés começam a fazer o mesmo. (CARNEIRO, 1991, p. 40, grifo nosso)

Qual a origem social de Natividade, que tipo de clientela e afiliados atraía e que significados pode ter sua "inovação" no piso da casa são questões que não tiveram lugar em um dos textos “clássicos” nos estudos sobre religiões afro-brasileiras. Apenas o encadeamento das frases sugere haver uma conexão de sentido entre a escolaridade do sacerdote e sua atitude, e é corriqueiro encontrarmos apenas breves frases constatando que entre a clientela ou entre os ogãs de um terreiro há pessoas de situação econômica mais favorecida ou mesmo da "elite" econômica e política da região, o que consistiria em uma inegável fonte de prestígio e recursos econômicos para o grupo de culto. (SILVERSTEIN, 1979; DANTAS, 1988; BRAGA, 1999; PRANDI, 1991) Prandi chega mesmo a sugerir que o cargo de ogã foi criado para dar uma posição religiosa a pessoas que poderiam obter benefícios para os terreiros:

No caso do candomblé, este fizera-se cercar desde seus primórdios de pessoas influentes na sociedade: profissionais intelectuais que nutriam pela religião dos negros simpatia e admiração e que mantinham com os terreiros de candomblé e seus dirigentes laços afetivos e de solidariedade. Os candomblés criaram para essas pessoas um cargo hierárquico que representava uma espécie de pai 
protetor, o ogãa, a quem cabia estabelecer uma espécie de ponte entre o terreiro e o mundo branco, protegendo o grupo de culto da perseguição policial, resolvendo problemas burocráticos e políticos, ajudando financeiramente no provimento dos ritos. (PRANDI, 1999, p. 101, grifo do autor)

Em "Mãe de todo o mundo: modos de sobrevivência nas comunidades de candomblé da Bahia”, Silverstein (1979) centrou sua análise justamente na relação de poder desenvolvida entre mães de santo (mulheres, negras e pobres) e homens de classes mais elevadas. Para a autora, a capacidade de atrair homens em posições sociais dominantes para o cargo de ogã seria um componente fundamental do prestígio e da "força" de uma sacerdotisa que, assim, lograria ter mais recursos para atender às necessidades religiosas de seu grupo e mais "poder", tanto social e econômico quanto religioso. Portanto, a presença desses sujeitos - sempre homens que não entram em transe - nos terreiros foi analisada sob a perspectiva das "estratégias" desenvolvidas por essas mulheres para a reprodução e expansão do grupo de culto. Embora seu artigo traga importantes contribuições para a compreensão das relações de poder entre os terreiros e a sociedade abrangente (ou melhor, entre "mães de santo" e "homens", numa sociedade que privilegia as posições masculinas), a perspectiva escolhida não permite que as experiências religiosas desses sujeitos, “estrategicamente seduzidos” pela religião, sejam levadas em conta. Assim, não é possível entrever que relações estes indivíduos estabeleciam com o candomblé, mas apenas o inverso.

Tais posições chocam-se frontalmente com a de Braga (1999), que procura enfatizar tanto as funções "diplomáticas” e "burocráticas" dos ogãs quanto o exercício de atividades propriamente religiosas. Como sustenta o autor, e também Augras (1983), uma boa parte do quadro dos ogãs é recrutada entre parentes e vizinhos, pessoas já conhecidas dos membros da casa e familiarizadas com o universo das religiões afro-brasileiras. Curiosamente, os mesmos textos que con- 
sideram o ogã típico como o "homem em situação social superior" exploram somente as benesses que fluem da posição deste homem para o grupo religioso, sendo o outro o lado da questão quase sempre negligenciado:

Se o candomblé pode ser eventualmente beneficiário de uma ajuda, o ogã está permanentemente protegido do ponto de vista religioso, o que para muitos traduz-se em satisfação e recompensa indescritíveis. (BRAGA, 1999, p. 57)

E o que dizer quando este homem de classe superior não se limita mais a ocupar a posição de ogã e passa a atuar de forma mais variada no grupo de culto? Ou quando não são apenas mulheres pobres, negras ou pouco escolarizadas que estão na roda, como filhas de santo? E sobre as mulheres que exercem as funções rituais mais "racionalizadas”, as equedes, cujas atividades decorrem de seus cargos e são pouquíssimas vezes mencionadas nas pesquisas sobre candomblé?

No célebre trabalho de Dantas (1988) sobre a construção da "pureza nagô", as pessoas de camadas sociais mais favorecidas aparecem, basicamente, de duas formas: como os intelectuais que, voltando-se para o candomblé como objeto científico, imiscuíam-se na disputa interna ao campo religioso por poder e prestígio, acabando por difundir a ideia da superioridade dos cultos de origem nagô; ou então como a clientela mais abastada do terreiro onde a pesquisa foi efetuada, clientela que (apesar de afastada dos cargos da casa), além de recursos financeiros, podia oferecer proteção política à comunidade. No caso em questão, seria realmente difícil que a autora tratasse dessas pessoas de outra forma, uma vez que ela afirma ter sido a estratégia escolhida pela casa estudada a de não ampliar a família de santo para incluir possíveis aliados (DANTAS, 1988, p. 197-234), evidenciando vias diversas daquelas retratadas por Silverstein para o caso baiano. Neste último, a opção foi "estender" a família de santo para abarcar seus “protetores”, que eram "suspensos ogãs” (quer dizer, escolhidos por um orixá para ocupar um cargo no terreiro), criando-se assim um vínculo entre as casas e os senhores eleitos, mesmo que es- 
tes nunca viessem a passar pelos rituais de confirmação. Na situação analisada por Dantas, embora as relações do terreiro com pessoas em posições mais favorecidas sejam mostradas de forma mais nuançada (nem sempre íntima e harmoniosa), elas não constituem exatamente o foco da análise e acabaram por retornar para a marginalidade que vêm ocupando na literatura especializada.

Já Prandi (1991) chega a colocar a questão de quais interesses o candomblé poderia atender para aqueles que dele se aproximam, como fiéis ou como clientes, na grande São Paulo contemporânea. A religião tanto pode ser atraente pelos serviços mágicos que oferece sem exigir vínculo duradouro, quanto pela constituição de seu espaço social e sagrado, ou seja, espaço onde o fiel trafegará pelos diferentes níveis hierárquicos - o que pode ser percebido como uma forma de "ascensão social simbólica" - e onde poderá encontrar novas formas de expressão. (PRANDI, 1999, p. 84-90) No entanto, o autor parece atribuir demasiada ênfase à distinção entre "membros" do terreiro, em sua maioria pobres (a quem interessaria o aspecto da "mobilidade social") e sua "clientela" interessada na manipulação mágica do mundo. Tal distinção deve ser tomada com todas as ressalvas possíveis. (BAPTISTA, 2009) Em primeiro lugar, para que alguém procure um terreiro, mesmo que esporadicamente, em busca de soluções para seus problemas, por mais pontuais e mundanos que sejam, é preciso que esta pessoa considere o candomblé como uma possibilidade de solução. Assim, aqueles que procuram os "serviços mágicos" dos sacerdotes compartilham alguns pressupostos básicos, no mínimo, de que se trata de um "lugar onde se pode ir" e no qual se pode encontrar alguma ação efetiva, isto é, esta religião deve estar no horizonte do sujeito. A distinção muito rígida entre os fins propriamente religiosos e a "manipulação mágica" também é um tanto problemática, como aponta o próprio Weber (1991, p. 293-294, grifo nosso) ${ }^{49}$

49 Ver também Weber (1991, p. 292) para "oração" e (1991, p. 293) para o "sacrifício". 
É possível distinguir a 'magia', como coação mágica, daquelas formas de relações com os poderes supra-sensíveis que se manifestam como 'religião' e 'culto' em súplicas, sacrifícios e veneração e, em conformidade com isso, designar como 'deuses' aqueles seres religiosamente venerados e invocados, e como 'demônios' aqueles forçados e conjurados por magia. A distinção quase nunca pode ser feita em profundidade, pois mesmo o ritual do culto 'religioso', neste sentido, contém quase por toda parte grande número de componentes mágicos. E o desenvolvimento histórico dessa distinção deve-se com freqüência simplesmente ao fato de que, no caso da repressão de um culto por um poder secular ou sacerdotal a favor de uma religião nova, os antigos deuses continuaram existindo como demônios.

Em segundo lugar, é muito comum que a relação de uma pessoa com um terreiro se inicie com a busca de alívio para alguma aflição e, posteriormente se aprofunde na iniciação (AUGRAS, 1983; RABELO; MOTTA; NUNES, 2002; RABELO, 2008), o que torna instáveis as associações pobres $=$ fiéis $=$ sempre presentes e de classe média $=$ clien tes = esporádicos. É bem possível que a cidade de Salvador, onde o candomblé tem hoje uma visibilidade relativamente grande, fazendo parte de sua imagem "oficial” (SANSONE, 2000; SANTOS, 2005), apresente uma especificidade com relação à São Paulo que se traduza num certo "reconhecimento" bem difundido da existência desta religião, colocando em cheque tais distinções que seriam operantes no caso de São Paulo. Entretanto, as trajetórias que levam fiéis, clientes, visitantes ou amigos da casa aos terreiros - sejam eles ricos ou pobres - não foram exploradas nem se deixou espaço para as experiências que estes vivem em tais percursos. Os diferentes interesses que o candomblé pode vir a atender para membros de camadas sociais diversas, assim dicotomizados, perdem de vista a força do que é especificamente sagrado no candomblé - manifestação ${ }^{50}$ das divindades e

50 A distinção entre "êxtase", "transe" e "possessão" na literatura acadêmica é problemática, uma vez que, de maneira geral, procura-se distinguir modalidades de experiência a partir de seus traços observáveis, e muitas vezes exteriores, como "quietude" ou "agitação", ou entre o 
oferendas - para a análise da constituição das identidades das pessoas que o procuram. Talvez os modelos explicativos acima mencionados sofram de um excesso de rigidez que cristaliza as possíveis relações no e com o terreiro em torno de pares de oposições (mulheres/homens; intelectuais/nativos; pobres/ricos; fiéis/clientes), e todas as nuances das formas de inserção e participação religiosa que não podem ser enquadradas em binômios tornam-se residuais e até mesmo invisíveis por não caberem, de fato, na análise.

Tal como mostram Amaral e Silva (1993) e Oro (1998), o ingresso de pessoas das camadas mais favorecidas nos terreiros se dá em meio a uma série de conflitos, choques e também busca por soluções. O trabalho braçal para a manutenção do templo e a preparação das cerimônias é um vasto palco para a emergência de clivagens de classe e raça que Amaral e Silva (1993) analisam segundo as interpretações oferecidas pelos próprios membros dos terreiros, ou seja, de que os filhos "brancos e ricos" trabalham menos, enquanto os mais pobres e escuros fazem a maior parte do trabalho pesado, reproduzindo, assim, no espaço religioso, as desigualdades e os preconceitos operantes em outros contextos sociais - acusação comum também no terreiro que acompanhei, diga-se de passagem. Dessa forma, mantêm-se dentro do terreiro as avaliações acerca de quais tipos de pessoas são adequadas a que tipo de tarefas. Os conflitos tornam-se mais acirrados ainda na medida em que os adeptos com melhores condições financeiras têm mais facilidade para arcar com os rituais que marcam sua idade de santo e, assim, podem ascender mais rapidamente na hierarquia da casa. (AMARAL; SILVA, 1993, p. 102) Os autores tratam ainda da questão da busca por legitimidade no interior do grupo de culto, indicando as estratégias dos dois "grupos" de adeptos num jogo conflituoso onde a cor da pele é convertida em

que seria o "comportamento" e o que seria sua "interpretação nativa", por exemplo, "saída de si" ou "intrusão de um espírito". (LEWIS, 1977; ROUGET, 1985; MAUÉS, 2003) Para uma crítica a estas distinções ver Crapanzano (1977). Assim, os termos transe e possessão, quando aqui utilizados, o serão como sinônimos de "manifestação", "incorporação", "passagem do orixá" ou "descida do santo", termos muito mais frequentes entre as pessoas acompanhadas. 
maior ou menor prestígio (é a real herança africana versus a situação socioeconômica mais baixa) a depender do contexto da disputa.

Já Oro (1998) revela que, em Porto Alegre, esse tipo de conflito é acompanhado por uma "distribuição" desigual dos adeptos entre terreiros chefiados por sacerdotes mais abastados ou menos, brancos ou negros, seguindo as mesmas relações “[...] parentais e de amizade, associadas à raça e situação social, mesmo na relação com as entidades espirituais" (ORO, 1998, p. 37) reproduzindo o mesmo modelo - e os mesmos preconceitos - vigentes fora do terreiro. Em outros termos, segue-se a lógica do estar entre "gente como nós", nas palavras de uma de minhas entrevistadas, Rosana.

Enfim, a presença dessas pessoas no candomblé começa a ser analisada. Os lugares que ocupam nos terreiros, as relações que desenvolvem, os conflitos em que se inserem e como procuram encontrar soluções práticas e teológicas para o fato de que, para o bem e para o mal, são provenientes de outros contextos sociais começam a ganhar visibilidade na literatura acadêmica. No entanto, embora os autores mencionados logo acima tenham utilizado enfoques relacionais, as experiências religiosas desses indivíduos e as trajetórias que os levaram a cruzar essas distâncias - tanto em quilômetros quanto em falta de familiaridade - ainda ficaram por analisar, talvez pelo simples fato de que não se tenha um trabalho monográfico dedicado ao tema.

As religiões afro-brasileiras, tal como qualquer outra religião, não constituem um universo à parte da sociedade em que existem. Como apontaram Dantas (1988), Amaral e Silva (1993) e Oro (1998), encontram-se inseridas em relações de poder desiguais. Encontram-se situadas ${ }^{51}$ por linhas de forças que as correlacionam com os agen-

51 Com isto quero dizer que as percepções, avaliações e práticas desenvolvidas para com estas religiões situam-se umas em relação às outras através das posições que ocupam com relação aos grupos de agentes que, historicamente, têm carregado essas mesmas práticas. Situar uma prática com relação a valores e apreciações não é o mesmo que procurar estabelecer determinações. Assim, não creio ser possível generalizar as situações aqui descritas para todas e quaisquer relações entre pessoas de certas camadas sociais e certos tipos de religiosidade. 0 que pode ser generalizado, caso se mostre adequado, é a construção metodológica do objeto. 
tes que as atualizam, legitimam, combatem ou denegam; encontram-se situadas frente a outras religiões - e às classes de agentes que as efetivam -, como se fossem "propriedades" de certos grupos de agentes. (BOURDIEU, 1989, p. 2001) Se considerarmos, porém, que estas linhas de força não constituem pura construção teórica, mas que podem traduzir algo relevante para a compreensão da experiência concreta de se viver numa dada sociedade, é preciso atentar para o cotidiano das pessoas envolvidas, pois é aí que se desenvolvem as relações que constroem e atualizam práticas e valores, preferências e avaliações, trajetórias individuais e interpretações. As escolhas e conflitos que podem ser relacionadas com posições sociais se dão no âmbito de ação de pessoas existentes, agindo com outros - e muitas vezes contra outros - numa miríade de situações afetivamente carregadas e nas quais comparecem como agentes encarnados, de fato, a única forma como podem comparecer. Assim, é preciso atentar para as nuances de engajamento na atividade religiosa - sem o quê uma religião corre o risco de tornar-se um corpus literário desprovido de vida - e, ao mesmo tempo, é possível procurar as correlações que classificam e estruturam a pluralidade das práticas. Se o candomblé passou por um processo de abertura ${ }^{52}$ a pessoas de origens raciais, sociais e até nacionais diversas, é relevante interrogar quais as marcas que estas pessoas podem estar imprimindo à religião, tanto quanto quais as especificidades que esta religião pode imprimir a seu modo de vida e à construção de suas identidades.

\section{A QUESTÃO DAS CAMADAS SOCIAIS E O CANDOMBLÉ}

Um dos temas centrais na análise weberiana da religião é o da importância de certas camadas sociais para o desenvolvimento de formas

Talvez seja preciso colocar a própria ideia de "abertura" em questão, já que tal processo parece ter uma longa história, havendo registro de tais pessoas nos terreiros desde o século XIX. (REIS; SILVA, 1989)s Pode ser mais apropriado pensarmos em um processo de maior visibilidade pública (SANTOS, 2005), o que, por sua vez, torna o candomblé uma opção viável para grupos sociais mais diversificados. 
específicas de religiosidade, já que certas mensagens e práticas tenderiam a atrair mais ou menos certos adeptos, a depender das afinidades eletivas entre as propostas religiosas e o estilo de vida da camada social em questão.

O tipo do estado empírico de bem-aventurança ou experiência de renascimento buscado como o valor supremo por uma religião variou, óbvia e necessariamente, de acordo com o caráter da camada que o adotou de forma mais destacada. A classe dos guerreiros cavalheirescos, as classes camponesas e comerciantes, e os intelectuais de educação literária tiveram, naturalmente, tendências religiosas diferentes. (WEBER, 1974a, p. 322)

Os intelectuais religiosos, especialistas educados em tradições literárias e rituais, tenderiam a influenciar a doutrina religiosa no sentido de uma maior racionalização teórica, de um ritualismo acentuado - como nas exigências de conformidade a obrigações tradicionais do confucionismo (WEBER, 1968) - ou do misticismo - como no caso do hinduísmo com sua ênfase na gnose como caminho de salvação - embora restrita aos próprios intelectuais religiosos. (WEBER, 1996) Historicamente, a emergência da primeira via dependeu do êxito de uma profecia exemplar, cujo emissário, normalmente, veio das camadas com um mínimo de cultura intelectualista, ou seja, embora dirigissem sua mensagem aos mais desfavorecidos, usualmente os profetas foram oriundos de camadas mais elevadas e com certo domínio literário (WEBER, 1991, p. 332) e talvez por isto estivessem preparados para questionar as mensagens aceitas e propor a "redescoberta" de seu sentido "verdadeiro". Já os intelectuais do hinduísmo, os brâmanes, compondo uma camada sacerdotal altamente especializada, não ocupada nem com a produção econômica, nem com o governo político, mas sim em manter sua própria posição de especialistas religiosos, direcionavam a religião no sentido das especulações acerca dos estados sagrados e das possibilidades e significados da salvação. No caso do confucionismo, o caráter altamente 
estatal e burocratizado de sua camada sacerdotal - isto é, com uma hierarquia de cargos alcançados através do estudo literário tradicional - imprimiu o forte acento ritualista, bem como a tolerância para com a magia e a fé em espíritos no "jardim mágico da crença heterodoxa” do Taoismo (WEBER, 1968, p. 227-229), embora estas fossem vistas com desdém e certo ceticismo pelas camadas chinesas mais educadas. Mais uma vez, tais tendências podem ser identificadas recorrendo-se a uma análise de desenvolvimentos históricos concretos. Nesse sentido, as próprias categorias utilizadas têm peso relativo e sua operacionalidade reside muito mais na aproximação entre elas (já foi comentado que, historicamente, as distinções são sempre fluidas) do que em sua aplicação isolada sobre as ênfases dadas em certos momentos de certas sociedades para combinações entre, por exemplo, manipulação mágica e súplica aos deuses.

No entanto, não apenas o caráter específico dos especialistas religiosos foi decisivo para as feições gerais que uma religião poderia tomar. Os leigos para quem os especialistas se dirigiam buscando atender às suas necessidades “materiais e ideais” também apresentaram tendências típicas de adesão a certos tipos de religiosidade, imprimindo a elas marcas próprias de seu modo de vida. As classes comerciantes tenderiam para um racionalismo de ordem prática, e as camadas camponesas a manter vínculos com concepções "mágicas" - em grande medida decorrentes da impossibilidade de racionalização completa de sua vida cotidiana dependente de fenômenos naturais - aderindo a religiosidades de caráter ético-racional apenas mediante compromissos efetuados entre tais promessas e seu modo de vida e sob condições ameaçadoras. (WEBER, 1991, p. 321336) As camadas "educadas" em geral, por sua vez, tenderiam a aceitar com facilidade religiões de tipo místico, aquelas com ênfase na experiência individual impossível de ser inteiramente comunicada de forma racional, encontrada, provavelmente, em sua forma mais radical no budismo antigo, cuja absoluta indiferença quanto à existência de divindades e completa rejeição da ordem do mundo 
fazia da aquisição da "tranquilidade" íntima e indiferente a única salvação possível. (WEBER, 1996, p. 205-206)

Como já mencionado, segundo este autor, um processo religioso de abstração teórica teria influenciado a visão de mundo de toda a sociedade moderna calcada, sobretudo, na imagem fornecida pelo cristianismo - especialmente em suas vertentes protestantes - "religião mundial" fortemente racionalizada no que se refere ao estabelecimento de princípios éticos abstratos, embora nem tanto em suas práticas rituais. Na verdade, Weber vai ainda mais longe, identificando no processo de racionalização a mola que impulsionou a religião para a esfera do irracional por excelência, cujo ápice acontece quando a experiência mística "inexprimível” passa a ser o "único além”, e a salvação só pode ser pensada no nível individual. (WEBER, 1974a, p. 324-325)

No caso histórico do protestantismo, a promessa de salvação, negativa com relação a este mundo, combinada a um ascetismo ativo (ao contrário do budismo antigo que pregava a não ação no mundo) orientou a condução da vida cotidiana de camadas cada vez mais vastas no sentido de uma ação metódica e contínua aprazível a Deus. Evidentemente, para que uma ética religiosa muito rigorosa não se perpetue como religiosidade restrita a um grupo de virtuosos (mais uma vez, como no budismo antigo), é preciso uma série de compromissos entre esta e o modo de vida das camadas que as adotam, por exemplo, no luteranismo, a ênfase no combate ao intelectualismo e ao liberalismo, característicos da burguesia urbana, e adequada às necessidades dos camponeses, acabou por resultar no "fenômeno moderno" da imagem do camponês como homem especialmente piedoso. (WEBER, 1991, p. 322-323) ${ }^{53}$

Seria então possível identificar algumas tendências semelhantes, por exemplo, em direção ao misticismo ou ao ascetismo, também entre as camadas "educadas” de hoje em dia? Quais seriam, então, as correlações que podemos estabelecer entre tais indivíduos, na Salvador de

53 Ver também as diferentes variações no desenvolvimento do protestantismo em Weber (2004). 
hoje e o candomblé? A que tipo de interesses esta religião pode atender para estas pessoas? Tenderiam elas a proceder a racionalizações religiosas, ou, ao contrário, a aceitar o irracional como característica própria da religião? Talvez, a princípio seja útil procurar algumas aproximações entre esta forma de religião afro-brasileira e os tipos de religião construídos por Weber.

\section{FORMAS DE PARTICIPAÇÃO NO CANDOMBLÉ: DIFERENTES POSSIBILIDADES DE INSERÇÃO INDIVIDUAL}

O momento mais público do candomblé reside nas festas em homenagem aos orixás. Nelas há música, o toque dos atabaques sagrados e as cantigas de louvação, pessoas e divindades dançam e há um repasto comunal que segue as preferências dos deuses. Um dos pontos fundamentais da festa é quando "o orixá desce", ou "baixa o santo". Na prática religiosa há um enorme número de rituais que vão desde os altamente complexos, que envolvem todos os membros do terreiro, às ações mais simples, que podem ser efetuadas em casa, passando por todos os tipos de ebós, pelo cuidado com os assentamentos e pelo próprio jogo de búzios. No entanto, os momentos mais ansiosamente aguardados e cuidadosamente preparados são aqueles que expõem a face pública da religião: as festas de orixá, as cerimônias finais das iniciações e as obrigações dos adeptos. Nestes momentos as divindades não podem faltar.

Os filhos de santo são preparados para a incorporação dos respectivos orixás através de um processo iniciático que apresenta as características de renascimento: "Este conceito é posto em relevo pela perda do antigo nome e a imposição, no final da iniciação, de um novo nome" (VERGER, 2002a, p. 139) ${ }^{54}$ Interpretação com a qual pai Dary concorda e a qual acrescenta o simbolismo da raspagem dos cabelos. Neste processo, podemos destacar uma série de elementos que constrói a morte do sujeito anterior, preparando-o

\footnotetext{
54 Ver também Verger (2002b, p. 36-49), especialmente das páginas 43-46.
} 
para o nascimento religioso: o período de reclusão durante o qual os iniciandos permanecem no terreiro, constantemente cuidados pelos “mais velhos", abandonando as roupas comuns, vestindo somente branco e tendo os cabelos completamente raspados, isto é, nas palavras de Turner, apresentando demarcadores que apagam as posições sociais na liminaridade do período iniciático (TURNER, 1974, p. 121-122), ,55 do qual o indivíduo emerge com um novo nome, um novo status, enfim, "uma nova vida”. O próprio corpo do iniciando foi tratado, manipulado e preparado para a incorporação das divindades (BASTIDE, 1983), num processo que tem por objetivo o despertar de um "carisma”, a manifestação de uma qualidade excepcional pensada como pessoal e intransferível. O renascimento "mágico" através dos rituais centrados na dança, música, comida, possessão pela divindade e sacrifício de animais tornam tentador classificar o candomblé como uma religião de caráter orgiástico, na qual os elementos mímicos do culto são extremamente relevantes para a manifestação do carisma dos iniciados, considerado como o mais alto valor sagrado. Desse ponto de vista, o candomblé apresentaria a possibilidade de uma experiência de transcendência pessoal e inexprimível que poderia operar como atrativo aos membros das camadas mais formalmente educadas, mas, por outro lado, a característica marcadamente sensorial e coletiva dos rituais também poderia colocar dificuldades ao seu ingresso.

No entanto, é problemático falar do candomblé como um tipo único de expressão religiosa, como já mostrou Prandi. Embora o autor enfatize seu aspecto ritualístico, não nega a importância de outros elementos na atração que a religião exerce sobre clientes e fiéis. (PRANDI, 1991, p. 73-213) ${ }^{56}$ Em primeiro lugar, mesmo os iniciados

\footnotetext{
55 Ver também Verger (2002b, p. 38-39)

56 autor também analisa a noção de "axé" como "carisma", isto é, uma qualidade excepcional que se traduz em força e poder que, do ponto de vista interno ao grupo, é responsável pelo seu sucesso e expansão. (PRANDI, 1991, p. 103-118) A mesma ideia pode ser encontrada em Silverstein (1979).
} 
preparados para a incorporação têm outras formas de relação com as divindades, principalmente fazendo oferendas e cuidando dos locais sagrados. Ainda que transformados em "recipientes" dos deuses, em qualquer momento eles podem ocupar uma eventual posição de "clientes do mago" quando precisam consultar os búzios - o que pode ser feito exclusivamente por uma pessoa em cada terreiro ${ }^{57}-\mathrm{e}$ realizar algum ebó com vistas a fins práticos. (BAPTISTA, 2009) Em segundo lugar, aqueles do grupo de culto que não entram em transe também são fundamentais. Ocupando os cargos de equede e ogã, estariam estas pessoas "menos ligadas" ao sagrado? Acredito que não. Sua eleição é feita diretamente pelas divindades, elas também se submetem aos rituais de iniciação que incluem recolhimento e, a depender da casa, raspagem da cabeça (expressão máxima do renascimento, segundo pai Dary), também ficam reclusas no terreiro durante a iniciação, ao término da qual são apresentadas à comunidade numa cerimônia em que se dá a conhecer seu novo nome, embora este seja pronunciado pela divindade que as elegeu, já que seu orixá pessoal "não desce".

Suas funções não são apenas "burocráticas”, pois também envolvem o contato com o carisma, o axé, tais como vestir e acompanhar os orixás que dançam, sacrificar animais e, a mais visível, tocar os tambores sagrados. Mais ainda, certos procedimentos rituais apenas podem ser executados por aqueles que receberam determinados cargos e, na sua ausência, pelo chefe do terreiro, desse modo, equedes e ogãs podem deter uma quase exclusividade sobre algumas tarefas. A “pureza” de seus corpos também é imprescindível para a execução de seus encargos, e eles devem se submeter às interdições específicas a suas posições, por exemplo, um ogã não pode ter contato com objetos sagrados se tiver mantido relações sexuais no dia anterior e não tiver sido "limpo" com o banho apropriado de ervas. Apesar de

\footnotetext{
Mais uma vez, uma série de exceções à regra podem ser encontradas, sobretudo quando o pai ou a mãe de santo passam por uma doença grave ou estão muito idosos, e outras pessoas assumem a tarefa de jogar os búzios.
} 
não serem "recipientes do sagrado", em sentido estrito, sua prática religiosa compartilha do caráter dos "magicamente renascidos", altamente marcada por tabus que delimitam o modo de manter seus corpos ritualmente "puros". Uma vez, ao questionar uma equede, durante uma festa, sobre o modo rápido como elas percebem a chegada de um orixá num filho de santo, obtive uma resposta bem direta: "É fácil, a gente sente a energia".

Sua autoridade, porém, decorre de seu cargo. Normalmente, os membros que não entram em transe não podem ser babalorixás ou ialorixás, as autoridades máximas do terreiro, e, ao contrário destes, podemos dizer que a fonte de sua autoridade não é carismática, mas decorre de uma "transmissão de carisma" em razão da eleição por uma divindade incorporada e dos rituais iniciáticos. Portanto, "feitura" e "confirmação" 58 apresentam algumas características bastante divergentes, ao mesmo tempo em que compartilham outras.

Equedes e ogãs "nascem adultos", e percorrem apenas implicitamente os estágios ${ }^{59}$ de status pelos quais os filhos de santo passam de modo explícito. Isso significa dizer que uma equede nova tem, efetivamente, status inferior a uma ebomi, porém esta distância diminui muito se a primeira foi socializada no candomblé desde a infância. Formalmente uma equede é considerada "mãe" dos filhos da casa ou, ao menos, "tia”. Um exemplo disso pode ser visto na obrigação dos iaôs de tomar a benção a "todos os mais velhos" ao chegar no terreiro, o que inclui equedes e ogãs que estejam presentes. Aliás, é importante ressaltar este aspecto do candomblé: a hierarquia não é baseada apenas na senioridade, embora este seja o princípio explicitado pelos grupos de culto, mas também na distribuição dos cargos. Por exemplo, ser Axogun - ogã que detém o privilégio e o dever de sacrificar os animais votivos - é uma posição de elevado prestígio,

58 Rituais de iniciação daqueles que entram em transe e daqueles que não entram, respectivamente.

59 O que chamo de "estágíos" são os anos de iniciação marcados pelas obrigações de um, três, cinco e sete anos, que representam alguma mudança no status do iniciado. 
já que esta função pode ser exercida tão somente por seu dignitário ou pelo chefe do terreiro. A distribuição de tais cargos importantes pode, inclusive, despertar ciúmes (AMARAL; SILVA, 1993, p. 102), uma vez que a determinação de quem deve ocupar cada um é, ao menos teoricamente, feita pelas divindades e pode "atravessar" outras posições - e expectativas - dentro do grupo. No Torrundê, durante os anos da pesquisa, o cargo de Axogum ficou sob a responsabilidade de um dos homens jovens de classe média que havia se iniciado há mais tempo. Nesse caso, contudo, nunca ouvi alguma fofoca ou comentário depreciativo a seu respeito, mesmo com suas limitações profissionais de disponibilidade e, talvez, isso se devesse à maestria com que aprendeu a desempenhar suas funções. Neste caso, temos um exemplo de como as posições de prestígio, as intrigas e o modo de inserção religiosa não são determinados por uma ou duas características do sujeito, mas processualmente estabelecidos num conjunto complexo de fatores.

Tal como filhos e filhas de santo (os que recebem as entidades em seu corpo), ogãs e equedes têm seus orixás de cabeça identificados pelo jogo de búzios, seu juntó ${ }^{60}$ e seu Exu e passam por um processo iniciático que envolve elementos de todas essas divindades, configurando uma espécie de identidade espiritual única, uma vez que se dá no entrecruzamento entre diversos seres espirituais (AUGRAS, 1983; GOLDMAN, 1985; SEGATO, 1995; NICOLAU-PARÉS, 1997):61 o orixá que os escolheu, o odu ${ }^{62}$ e as demais entidades pessoais. Um

60 Ou "segundo santo", é aquele que tem mais influência sobre a vida de uma pessoa logo depois do orixá de cabeça. A sequência de divindades que configura a identidade espiritual é conhecida como "carrego". Goldman (1985) se refere a sete orixás que são identificados numa ordem decrescente de proximidade com o iniciado. No Torrundê costumam ser identificados dois orixás já antes da iniciação, mas o número total não é pré-definido, dependendo do jogo de búzios.

${ }^{61}$ Ver também Bastide (1973).

62 Trata-se de um "caminho espiritual" traçado antes do nascimento que determina os tipos de "energia" que uma pessoa trará para esta vida. Estas energias não são os orixás - que são "energias da natureza", por exemplo, da água ou do vento - e dizem respeito a aspectos da vida como afetividade, saúde, equilíbrio financeiro etc. É uma espécie de "destino", porém 
ogã e uma equede suspensos, porém ainda não confirmados, permanecem no terreiro como abiãs tal qual aqueles que serão iniciados para incorporar seus orixás. Na verdade, podemos dizer que alguém cuja iniciação ainda não se deu - seja qual for a posição que ocupará no grupo de culto - encontra-se numa situação bastante ambígua. Por um lado, já houve um certo "chamado" da divindade e, assim, a provável posição de tal pessoa já foi explicitada. Por outro, há sempre o risco de que as expectativas iniciais não se cumpram, sobretudo no caso de abiãs que passam anos sem incorporar e acabam por não fazê-lo, a despeito da suspeita de que poderiam entrar em transe, e de ogãs e equedes suspensos, pois estes ainda podem cair no santo ao participarem de rituais mais restritos. Há uma brincadeira no terreiro que consiste em chamar abiãs que ainda não incorporaram de "é queda", sinalizando a indefinição de seu papel.

De toda sorte, para ser de fato um membro do candomblé é imprescindível que qualquer pessoa se submeta aos rituais iniciáticos que, segundo Goldman (1985), operam uma progressiva construção da pessoa. A iniciação no candomblé não se dá de uma vez por todas, sendo constantemente renovada nas obrigações, cerimônias públicas que comemoram, como já mencionado, os “aniversários” de um, três, cinco e sete anos de iniciação. Estas cerimônias, inclusive a iniciação propriamente dita, estabelecem e fixam a relação de um indivíduo com uma série cada vez maior de divindades. A princípio, esta se reduz ao orixá de cabeça, ao Exu individual, ao caboclo, nos terreiros que o cultuam, e ao erê particular, que sempre acompanha cada orixá, além do Egun, no caso analisado por Goldman. Para muita gente estas entidades já se manifestavam antes do ingresso no terreiro. Caboclos, erês e Exus são pródigos em aparições não anunciadas e, muitas vezes, surgem em casa para ajudar seus filhos, ou parentes e amigos destes. Não obstante, antes da iniciação tais manifestações

não fatalista, já que todas estas energias podem trazer um aspecto positivo e um negativo, cabendo ao babalorixá efetuar os rituais necessários para que todas elas atuem de forma construtiva na vida da pessoa. 
são consideradas um tanto instáveis, podendo ser muito mais prejudiciais do que benéficas. Como Goldman (1985) argumenta, o processo de iniciação individualiza as próprias divindades que passam a ter um nome próprio ${ }^{63}$ e uma representação material individualizada, o assentamento. Uma pessoa iniciada não é mais somente filha de Ogum, por exemplo, mas filha de um Ogum específico cujo nome foi anunciado publicamente no barracão. Ao longo dos sete primeiros anos de iniciação ${ }^{64}$, várias divindades são singularizadas dessa forma, construindo uma rede de relações na qual o iniciado termina por ocupar uma posição que é única e exclusiva. Assim, o vínculo com esta religião vai sendo lentamente firmado, ao mesmo tempo em que vai progressivamente construindo uma pessoa mais completa e equilibrada porque é singular em suas relações com o sagrado.

Nicolau-Parés (1997, p. 162-172) segue adiante nesta trilha mostrando como distintas ortodoxias, operando em terreiros de diferentes tradições, articulam diversamente a identidade espiritual individual que pode se dar num continuum que teria num extremo a incorporação de um único vodun ${ }^{65}$ - na Casa das Minas - e no outro a incorporação de uma ampla gama de entidades, organizadas por linhas pessoais, que podem, algumas vezes, não ter uma identificação bem definida. Assim, diferentes tradições culturais podem oferecer noções de pessoa distintas que permitem articulações diferenciadas das identidades espirituais dos membros de um terreiro. De toda forma, mesmo nos casos mais extremos, se mantém a construção processual dessa identidade e fica evidente a importância da experiência

\footnotetext{
63 No Torrundê este é o nome do orixá e não costuma ser usado. 0 nome de iniciado de um filho de santo é composto por partes do nome do orixá, mas não é o mesmo. De toda forma, tratam-se de nomes de uso restrito ao grupo de culto. Ver também Silva (1998, p.40).

64 Na maior parte dos casos, tais cerimônias não podem ser realizadas exatamente na data da iniciação. Uma série de empecilhos faz com que sejam, em geral, atrasadas, principalmente em virtude da necessidade de combinar obrigações de pessoas com disponibilidades muito diferentes para voltar ao recolhimento no terreiro e as dificuldades financeiras para realizar cerimônias complexas e caras.

65 Equivalente a orixá na nação jeje. Na angola o termo é inquice.
} 
da divindade no ritual para sua identificação. Aqui encontramos uma grande diferença entre a iniciação e a confirmação, pois é preciso lembrar que equedes e ogãs "nascem adultos", ou seja, seu status é alcançado de maneira mais imediata, embora tais "comemorações" se apliquem também a eles, conferindo-lhes prestígio gradativamente mais elevado, ao menos em terreiros com influência da nação angola. Também em seu caso há uma singularidade devida às relações individualizadas com a esfera do sagrado, embora esta possa não ser vivida de maneira tão marcante.

Podemos, portanto, dizer que o candomblé apresenta uma ambiguidade que torna sua tipificação uma tarefa ainda mais complexa, uma vez que se pode enfatizar seu aspecto institucional, onde a autoridade máxima e o fim sagrado procurado têm caráter carismático, ou pode-se enfatizar as experiências que esta forma de religião permite e suas consequências para os indivíduos e, aqui, as possibilidades se ampliam. ${ }^{66}$ Aliás, este pode muito bem ser o grande atrativo do candomblé para as camadas médias urbanas: apresentar várias formas de religiosidade no interior de um só grupo de culto, o que oferece ao indivíduo possibilidades de inserção, mas principalmente, de experiências religiosas diversas. Se, por um lado, a ênfase maior é dada à autoridade carismática em função da experiência do transe, há também, por outro, a possibilidade de se ocupar posições cuja autoridade e cujas atividades apresentam um caráter mais racionalizado, ou seja, que seguem regras já explicitadas e se configuram em cargos correspondentes. ${ }^{67}$

A própria estrutura da iniciação religiosa volta-se para a construção de posições individualizadas, possibilitando que cada um interprete sua história como uma conjunção única. Ao ingressar no

${ }^{66}$ É preciso não esquecer que há outro elemento fundamental além do transe: a oferenda. Um ebó pode ser tanto um elaborado ritual comandado pela iálorixá ou pelo babalorixá, ou uma simples oferta de algo que o próprio adepto entrega ao orixá no local adequado, e, portanto, pode ser feito por qualquer um que detenha os conhecimentos necessários.

67 Ver também Sansi (2007) para uma discussão sobre "dom" e "iniciação" como fontes de poder no candomblé. 
candomblé o indivíduo deixa para trás uma série de interpretações de si próprio, mas não para se anular frente ao divino, não para se despersonalizar. Ao contrário, como afirmou Augras (1983, p. 60-93), deixa-se muito de si mesmo para trás para expressar a sua "natureza mais profunda". (TURNER, 1974) Este é meu ponto: o candomblé apresenta características adequadas aos interesses ideais de pessoas que compreendem a si próprias como indivíduos que "optam" e é, portanto, o centro biográfico de histórias singularizadas por estas opções, e ainda apresenta uma especificidade: a passagem pelo rito de iniciação. Esta também favorece que a religião surja como um elemento de distinção pessoal frente à origem sociofamiliar. Desse ponto de vista, podemos dizer que para parcela da classe média de Salvador, o candomblé é uma religião que surge como "solvente" de outros laços sociais e fidelidades anteriores, corolário de ter-se tornado uma religião “universal”. (PIERUCCI, 2006)

Temos aqui duas facetas de um elemento que pode ser responsabilizado pela atração que o candomblé vem exercendo para membros da classe média escolarizada, a possibilidade de inserção e experiências religiosas distintas e o processo singularização religiosa. Resta, porém, ainda um aspecto da questão: a que expectativas a religião responde para que pessoas estranhas a procurem pela primeira vez? Para refletir sobre isso, convém analisar quais os motivos alegados para visitar os terreiros e para o ingresso na religião.

Pois bem, no caso das pessoas entrevistadas neste projeto, todas elas eram advindas de um universo católico e/ou espírita e num dado momento de suas vidas decidiram se iniciar no candomblé. Em que momento isto ocorreu? Para Paulo foi durante a infância e não podemos dizer que houve um ato de escolha em seu caso. Ele tinha apenas 8 anos quando sofreu um grave acidente, ficando hospitalizado entre a vida e a morte, e o caminho encontrado por sua avó materna para salvar o menino foi através do candomblé. Assim, Paulo foi o único dos entrevistados que cresceu na religião. Sua família continua católica e ele contou que mantém grande afinidade com 
esta religião. É interessante notar que Paulo contou a história de sua iniciação como algo complicado e assustador, mas já na adolescência, quando a família descobriu sua ligação com o candomblé, ele acabou por abandoná-la pela religião, inclusive deixando a casa paterna e passando por grandes privações. Somente aos 18 anos, quando passou no vestibular, Paulo iniciou uma reaproximação com sua família, recorrendo à mesma avó que o levou ao candomblé. Assim, embora a iniciação não apareça para ele como uma opção individual, sua trajetória mantém esse caráter em sua narrativa. Para todos os outros entrevistados essa ideia de religião como "assunto de foro íntimo" tem tom menos dramático e, ao mesmo tempo, mais afirmativo da noção de que a religião é uma opção individual. Fábio, o companheiro de Ana, me contou que não consegue compreender como "pessoas esclarecidas" podem deixar de levar seus filhos para o terreiro, no que Ana discorda, pois pensa que cada um deve decidir por si quando for adulto.

Reencontramos aqui um ponto que já foi destacado com relação às profissões exercidas, pois ambas as trajetórias aparecem como opções pessoais, como caminhos que se trilha em busca de "crescimento", seja espiritual, seja material e de autorrealização. Assim, o candomblé surge de mais uma maneira: como um caminho de autoconhecimento. Este ponto, porém, será retomado mais adiante devido à sua relevância para a discussão de identidades pessoais no presente caso. O que quero enfatizar, por ora, é a coincidência de perspectivas no que diz respeito à trajetória profissional e à religiosa.

Quanto aos outros entrevistados, Rosana e Francisco ainda não se iniciaram - e talvez nunca venham a fazê-lo - seis se iniciaram com cerca de 20 anos de idade e sete deles com 30 anos ou mais. Podemos distinguir aqueles que se ligaram ao terreiro ainda bem jovens daqueles que o fizeram já bastante adultos, mas as diferenças de opiniões e ideias nas entrevistas não são muito marcadas tornando difícil dizer se são produto da idade e/ou de características pessoais. De toda forma, para todos eles é importante a ideia de que optaram pelo candomblé como religião. 
Este tema reaparece, ainda, de outra forma. Dos motivos alegados para o contato inicial com a religião, Marta e Ana (ambas filhas de santo) começaram a frequentar o terreiro levadas pelos namorados. Ana conheceu o Torrundê através de Fábio, também filho de santo, somente por curiosidade pela religião do namorado. Marta foi levada por seu parceiro, que era apenas frequentador, assistiu a algumas cerimônias, mas adoeceu e precisou de uma consulta porque iria se submeter a uma cirurgia, desse modo foi também "por necessidade". Elas "foram ficando" no terreiro, conhecendo a religião e as pessoas até que acabaram por se identificar com o candomblé e passaram dois e quatro anos como abiãs, respectivamente.

Seis pessoas contaram-me que se aproximaram do candomblé por "curiosidade" ou um "interesse cultural" um tanto inespecífico. Dois ogãs e dois filhos de santo narraram um despertar do interesse pelo aspecto estético do candomblé ou por o considerarem como um patrimônio cultural digno de maior atenção. Este é o caso de Francisco, que devido à curiosidade despertada pela leitura de trabalhos acadêmicos procurou um terreiro para um jogo de búzios, gostou do pai de santo e começou a frequentar as festas. Irene pode ser considerada um caso exemplar dessa situação. Ela desejava fazer um projeto de mestrado em Pedagogia que valorizasse a "cultura negra" na educação infantil. Por esse motivo foi levada por uma amiga a conhecer o terreiro do qual esta participava há quase duas décadas:

Mas o [terreiro], a pergunta que você me fez, o [terreiro], veio, olha, em, em tese, pra mim como uma consequência [do trabalho acadêmico que ela vinha desenvolvendo], agora, se considerar, é, a nível dos, desígnios do orixá, da vida espiritual de uma pessoa, eu acho que toda a vida eu fui de Oxum.

Ernesto foi apresentado à sua mãe de santo por uma conhecida pelo fato de ter morado três anos e meio na África. Fábio nem sabe dizer ao certo porque começou a ir ao terreiro. Ele pertencia a uma turma de amigos do bairro da Barra quando um deles começou a fre- 
quentar o candomblé e levou os outros. Numa espécie de aventura adolescente (e contestatória, podemos dizer, a partir dos conflitos familiares que tais “visitas” causavam), os rapazes começaram a trabalhar nas obras do terreiro, em Paripe. Muitos desistiram, mas três deles se iniciaram e dois continuam atuantes. Temos, então, dois motivos básicos para se procurar um terreiro: a necessidade de uma consulta ou a curiosidade. Como também já foi mencionado, podemos imaginar que o "interesse cultural" tem alguma relação com o movimento de contracultura e de valorização de uma certa "autenticidade" que, no caso de Fábio, soma-se ainda a uma contestação juvenil. Assim, para muitas dessas pessoas escolarizadas o candomblé surge como um objeto cultural digno de atenção. (PRANDI, 1999; SANSI, 2003) Já os motivos para o ingresso não são claros. As pessoas "gostam” da casa, "gostam" do pai ou mãe de santo, vão "ficando" e acabam por se iniciar, tanto aquelas que foram procurar por serviços espirituais quanto as que foram por curiosidade, como Antônia que, "quando viu, tava de saia”.

$\mathrm{Na}$ verdade, a amizade com alguma pessoa de candomblé tem sido fundamental na descoberta da religião, já que os familiares dos entrevistados não costumavam frequentar terreiros e, quando o faziam, não eram familiares próximos (como as tias de Ana e de Pedro) ou simplesmente não os levavam, como o pai de Marta, cuja avó era filha de santo e ela nem sabia disso. Como vimos, os colegas de faculdade e de trabalho têm um papel importante neste momento, pois em geral são eles que iniciaram o contato entre os entrevistados e o terreiro. Em apenas um caso, Paulo, foi a avó que o fez, através de uma vizinha. Isto reforça a ideia de que há um distanciamento da família no início destas trajetórias religiosas. Já a relação de amizade com o líder do terreiro tem se mostrado importante na decisão de ingressar na religião. É o caso de Helena, que me contou sua busca por um caminho espiritual pessoal (tendo conhecido o catolicismo, o kardecismo e a umbanda paulista) e que, ao descobrir que um amigo seu era pai de santo, decidiu participar ativamente, acabou sendo 
suspensa e se confirmando equede. Dois ogãs também disseram que "foram ficando" pela amizade que passaram a nutrir pelos sacerdotes de seus respectivos terreiros.

Antônia foi levada ao candomblé por uma amiga, por estar passando por um momento de grande desorganização de sua vida pessoal, com problemas familiares, financeiros e de saúde. De início ela foi fazer uma consulta e os trabalhos necessários, mas, então, contoume que foi desenvolvendo uma grande amizade pela mãe de santo e gostando da religião. Começou a participar das atividades como abiã e, quatro anos depois, foi suspensa equede. Hoje ela tem 10 anos de iniciada. O babalorixá Robson também foi levado a um terreiro por um amigo para conhecer a religião, não gostou do ritual a que assistiu, mas voltou porque se encontrava em um momento de crise pessoal e pensou que poderia encontrar a solução para seus problemas através do candomblé. Como transparece na sua fala que abre este capítulo, hoje, ele pensa que este não é um motivo legítimo para o vínculo religioso, pois a transformação que a religião opera "é interior". Equede Hortência é mais uma pessoa que foi levada ao candomblé por um amigo, pai Dary, que hoje é seu pai de santo. Na verdade, ela já havia assistido a uma entrega de decá, há cerca de 27 anos, mas não se interessou pela religião na época. Por volta de 1994, porém, foi convidada pelo babalorixá, que ela já conhecia e sabia ser uma "pessoa respeitosa", resolveu ir ao terreiro recém-aberto, gostou, foi ficando e logo depois foi suspensa. Ela afirma que já conhecer o caráter de seu amigo foi o que mais pesou para que ela imediatamente se sentisse à vontade para aceitar o cargo, pois pressentiu que ficaria ali "para o resto da vida”. Para Fábio foi o fato de ser um terreiro novo e cheio "de gente jovem" o que pesou. Pai Dary, para ele, apesar de ter mais idade, tinha a "cabeça" dos jovens.

Por outra via chegamos novamente ao mesmo ponto: a convivência no terreiro, para estas pessoas, não se dá no âmbito das relações familiares, mas sim no das relações de amizade e coleguismo. Isto, porém, não significa que tais relações se desenvolvam a partir 
da convivência no grupo. João Alfredo foi exemplar a esse respeito. Quando perguntei se ele havia desenvolvido amizades no terreiro, ele respondeu:

Ah, sempre! Aqui, é, você faz muita amizade porque vem muita gente de fora, né? Muito politico, vem muito empresário, tudo, a gente termina fazendo amizade também.

Para os entrevistados não foi algo problemático admitir que as amizades criadas no terreiro se deram entre pessoas do mesmo nível de escolaridade e da mesma classe, com raras exceções, uma vez que isto ocorre no desenvolvimento de suas relações de amizade de maneira geral. O grupo religioso não representa, para essas pessoas, uma grande oportunidade de ampliar suas relações sociais. Ainda que esta possibilidade não seja excluída de todo, ela é quase limitada aos contatos que poderiam ocorrer em vários outros ambientes, como escolas e faculdades, redes de amigos ou mesmo via internet, hoje em dia. No geral, o terreiro enquanto conjunto humano é sentido como um local de fofocas, invasão de privacidade e conflitos, muito mais do que como uma rede capaz de oferecer apoio a seus membros. Com isto não quero dizer que os membros desta classe média escolarizada não recorram ao terreiro em momentos de crise, nem que não encontrem apoio ali, mas este aspecto não é valorizado - muitas vezes sequer é mencionado - ao passo que as situações negativas são sempre exploradas nas entrevistas.

De toda forma, os motivos alegados para entrar em contato com um terreiro podem ser divididos em dois grandes grupos. De um lado temos aqueles que se encontravam em uma situação problemática e que foram a um terreiro pela primeira vez para um jogo de búzios e, a seguir, para os ebós prescritos. Estes poderiam ser classificados como "clientes". Mais uma vez, é preciso ter em mente que alguém não se dispõe a se apresentar como "cliente" de uma religião sem que seu horizonte de possibilidades apresente tal prática como possível. Como vimos, aqueles que procuraram um terreiro para a solução de 
problemas imediatos o fizeram com o auxílio de um amigo, da mesma maneira como poderiam ser aconselhados a procurar um "psicanalista formidável”. Com isto quero dizer simplesmente que a distinção analítica entre esferas da ação humana deve ser contrabalançada com o fato de que na vida individual é uma mesma pessoa que "trafega" entre todas elas, e o "cliente" um dia se torna "filho" da casa. Este ponto fica mais claro ao tratarmos do outro grupo: as pessoas que foram a um terreiro por "interesse cultural". O que significa ir conversar com uma mãe de santo para trocar impressões sobre a vida na África? Ou frequentar um terreiro porque se leu ou se quer escrever a respeito? Não seria esta uma visão um tanto “secularizada” da própria religião?

Um terreiro é um lugar onde alguém pode ir em busca de "cultura" e não do "sagrado" propriamente ${ }^{68}$ dito. É claro que pode ser difícil manter esta noção atuante após a iniciação, quando se deve, ao menos em tese, reconhecer a força e a liberdade de ação dos orixás, mas isto não impede que algumas pessoas a reconheçam como motivação inicial do interesse pela religião. Irene, que chegou a fazer “apresentações” das danças dos orixás antes de conhecer o terreiro a que pertence comenta:

Irene - Então ele [o amigo do candomblé] olhou pra mim e disse: 'é uma, é um congresso'. E que a gente ia dançar. Eaí ele fez, 'Dance Oxum'. Cê vê, hoje eu sô terminantemente contra isso porque não faz o menor sentido, né? Alguém se vestir de orixá e dançar a dança do orixá. Hoje eu vejo que na época foi uma coisa tão... inocente. E ele disse: 'você, acho que você é de Oxum. E você é de Oxum Apará'. Quer dizer, até a qualidade da Oxum ele deu, né? E dai por diante eu era de Oxum. Mas sem maiores consequências, eu não sabia, porque hoje tem, tem arquétipos até junguianos, né? Que se coloca, que se leva como referencial, mas eu não... esse foi o meu primeiro contato com a palavra Oxum.

68 Ver Sansi (2007) para uma discussão do sincretismo como processo histórico-cultural que, no caso particular do candomblé, possibilitou a construção da imagem pública do "candomblé como cultura", num intercâmbio entre especialistas religiosos e intelectuais. 
Luciana - Mas por que você ia dançar, se você não tinha $[\ldots]$.

Irene - Porque no congresso precisava apresentar uma dança que representasse a Bahia.

O que não estava colocado de antemão para estes adeptos como possibilidade era exatamente isso: as divindades como agentes. $\mathrm{Ou}$ seria apenas a possibilidade de que qualquer divindade seja encarada como agente? Este é o tipo de questão para a qual não se encontra resposta, mesmo porque as pessoas não saberiam respondê-la, em muitos casos por nunca terem pensado sobre isso. Na verdade, tanto faz uma afirmativa como a outra já que as duas têm o mesmo pressuposto: desconsiderar que a categoria especial de agentes, desencarnados, diria Sansi (2003, p. 135), com os quais se tem que negociar e lidar, é uma proposição específica a cada grupo religioso. A partir disso percebe-se que tanto desconhecer a atuação desses agentes, quanto considerar qualquer um como equivalente representam duas possibilidades do mesmo mundo: aquele em que a religião não é uma instituição que perpassa todas as esferas de nossa vida (e este pode muito bem ser um dos pontos mais afetados pelo vínculo com o terreiro). Mais uma vez, nos deparamos com uma situação que pode ser chamada de sociedade secularizada, onde várias alternativas religiosas - e várias formas de ver a mesma religião - podem conviver e na qual um indivíduo pode trafegar por várias delas. Entretanto há algo que pode ser mais forte para o caso de pessoas escolarizadas de classe média: a ênfase numa dimensão cultural. Como vimos no primeiro capítulo, para estas pessoas a distinção de classe passa pela "educação" e pela "cultura". Assim, num ambiente em que o candomblé é apresentado como "cultura autêntica", como é a cidade de Salvador, o resultado do "sincretismo cultural" (SANSI, 2007) efetuado por religiosos e acadêmicos pode ser mais um dos atrativos para os membros da classe média. Mas uma vez que se chega a um terreiro, como se interpreta a religião? 


\section{RELIGIÃO COMO ESFERA DO IRRACIONAL: DE ONDE SE ESPERA QUE VENHA A RACIONALIZAÇÃO?}

Considerei acima a hipótese de que as camadas médias poderiam ser portadoras de grandes ambiguidades no que toca aos tipos de religião que lhes atraem e que poderiam, portanto, aceitar religiões altamente racionalizadas tão bem como expressões da religião como esfera do irracional, ao modo das camadas "cívicas” de que falava Weber (1974b, p. 327):

Finalmente, podemos considerar as camadas "cívicas" no sentido que a palavra tem na Europa ocidental, bem como as camadas que a elas correspondem em outros lugares: artesãos, comerciantes, empresários dedicados ao artesanato e seus derivados, que existem apenas no Ocidente moderno. Evidentemente essas camadas foram as mais ambíguas com relação às posições religiosas que lhes estavam abertas.

Agora se faz necessário confrontar esta possibilidade com a situação particular encontrada entre as pessoas investigadas. No início das análises, parti do pressuposto de que a possessão, por ser uma experiência individual inexprimível verbalmente, consistiria numa "irracionalidade" com a qual era preciso aprender a lidar, principalmente no caso do candomblé, onde o modelo de manifestação das entidades exige a ausência de memória de quem a vive. No entanto, este ponto não se sustentava diante das experiências e receios narrados nas entrevistas. Quando perguntadas sobre a possessão, sobre sua reação inicial à presença das divindades nos corpos dos iniciados, as maneiras pelas quais estas pessoas manifestaram espanto ou descrença foram por demais variadas e contraditórias para permitir qualquer tomada de posição com relação à "irracionalidade" da experiência da incorporação. Embora pudessem duvidar da presença efetiva das entidades em alguns casos particulares, o que é comum ocorrer no candomblé, principalmente nos primeiros contatos com terreiros, isto não significa que houvesse algum tipo de expectativa de racionalização dessa prática religiosa. Mesmo 
aqueles que passaram a receber orixás, caboclos e erês revelaram uma espécie de receio que nada tinha de específico para uma classe ou ausência de contato anterior com a religião. Ana, por exemplo, contou que no início seu orixá não "passava completamente" e ela se sentia "muito mal", perdia o equilíbrio e o controle motor sem "perder a consciência”. Ela também tinha dúvidas quanto à legitimidade de sua experiência. Entretanto, este tipo de "desconforto", de dúvida e receio é frequente nas primeiras experiências de incorporação mesmo para pessoas que frequentaram um terreiro desde crianças. O que é mais interessante em seu discurso é que até hoje ela não gosta de receber Iansã em outros terreiros aonde vai como visitante e muito menos de "ficar de erê", pois tem um pouco de vergonha de se portar como uma criança pequena e mal educada.

O medo de "sair do ar" e perder totalmente a consciência, que Rosana expressava, me levou a pensar que uma experiência anterior no espiritismo poderia ser responsável pela familiaridade com a manifestação que muitos entrevistados relataram, pois já teriam contato com a manifestação de espíritos, embora num modelo oposto, que exige a lembrança dos eventos ocorridos. Para o babalorixá Robson, porém, cuja trajetória religiosa inclui a passagem pelo espiritismo na função de médium, a incorporação não representou sua maior dificuldade no início do contato com os membros do terreiro, a despeito de ter contado que pensou estar sofrendo um derrame na primeira vez que Obaluaiê passou, pois viu suas mãos e braços se entortarem sem controle de sua vontade até que caiu no santo completamente. "Fui carismática, né? Depois achei que é bem mais fácil receber Oxum do que Jesus Cristo", contou Irene. Portanto, as variadas reações que foram expressas e os percursos que levaram as pessoas de um certo estranhamento - que nem sempre ocorreu - a um certo receio e, finalmente, à normalização eram bastante comuns nas histórias de membros do candomblé e não me permitia tirar qualquer conclusão sobre uma possível aceitação do "irracional” na prática religiosa, além de ser comum a pessoas de outras classes e outras ori- 
gens religiosas. As respostas de duas equedes são ilustrativas do problema enfrentado:

Quer dizer, tirando o medo de dar santo, que todo o mundo tem, não teve conflito nenhum. [...] A incorporação 'nos outros', [risos] foi sem complicação nenhuma. Não teve complicação, não. (Antônia, ênfase na entonação).

Porque eu acho que é uma coisa que de uma certa forma, interfere na sua vida pessoal, profissional e tudo o mais, né? Eu mesma perguntava, falei: 'meu Deus, que coisa, né? Será que eu ia querer, é, receber, fazer, ter que aceitar, ter que fazer, ter que receber as pessoas, ter que dizer, ter que fazer os trabalhos e tudo o mais'? Não sei. No meu caso eu não, não recebo nenhuma entidade, mas eu acho que deve ser uma coisa que cria um certo conflito. (Helena)

Afinal, há "complicação” ou não? Trata-se de uma experiência que se admite para os outros e não para si? As respostas obtidas eram altamente ambíguas, não permitindo qualquer conclusão. Por vezes parecia haver um conflito no início do vínculo religioso que se diluía com o tempo. Por vezes esse conflito parecia permanecer, embora restrito às incorporações fora do próprio terreiro. Outras vezes ele parecia ser afastado pela iniciação, que eliminava esta possibilidade. Enfim, o problema residia em partir do princípio de que a incorporação era essencialmente uma experiência irracional. Como argumentou Bastide (2001), a possessão tem lugar na estrutura de um ritual, aliás, ela mesma é um ritual, e, mesmo excluindo a lembrança dos atos praticados, não exclui a comunicação entre os participantes, ao contrário, exige uma fina interação entre eles. Apenas esta comunicação não ocorre segundo os modelos de transmissão que normalmente consideramos "racionais". A incorporação das divindades, portanto, só pode ser compreendida como valor sagrado a ser alcançado, e as maneiras como isto deve ocorrer são altamente regulamentadas. Nicolau-Parés (1997, p. 177-197) mostra como a incorporação por diferentes entidades é articulada entre enquadramentos rituais específicos e concepções acerca 
das identidades desses seres, correlacionados às tradições específicas de cada terreiro e suas casas matrizes.

O que era expresso nessas respostas não dizia respeito à irracionalidade, mas sim, novamente, àquela possibilidade de mais de um tipo de experiência no mesmo grupo de culto. Religiosamente o transe não é para todos. Alguns são escolhidos para receber as divindades em seus corpos e outros para cuidar das divindades fora de seus corpos. Sociologicamente o transe tampouco é para todos: nem todas as pessoas entretêm expectativas semelhantes quanto a suas experiências religiosas. Embora isto possa ser generalizado para qualquer classe social, parece particularmente adequado a pessoas que compreendem seu vínculo religioso como uma espécie de carreira pela qual se optou. "Decidir" se iniciar num terreiro não significa se adequar a um só papel religioso, se conformar a uma forma de atuação. A própria estrutura do culto religioso já oferece, logo de partida, duas possibilidades de inserção que exigem experiências religiosas distintas: uma que envolve a incorporação de divindades e outra que a proíbe.

Por outro lado, há uma série de regras e comportamentos aos quais é necessário se conformar para ingressar num terreiro. A mais visível delas diz respeito à hierarquia religiosa. Como já foi mencionado, aprender a respeitá-la, saber quem ocupa qual posição no grupo e qual o tratamento adequado para com tal pessoa foi um processo delicado para os entrevistados. Aqui podemos imaginar que o problema não está diretamente relacionado à classe social, mas sim à familiaridade, ou sua falta, com o universo religioso em questão. Tudo seria um problema de desconhecimento de um código de conduta coletivo, se não fosse por um aspecto diretamente ligado à hierarquia e que tem apresentado certas peculiaridades: a autoridade.

Os cargos distribuídos pelos orixás e os graus de senioridade iniciática constituem a base da autoridade dos membros de um terreiro, cujo ápice encontra-se na figura da mãe ou pai de santo. Estes detêm a última e incontestável palavra sobre tudo, especialmente porque devem traduzir a vontade das divindades (lembremos que só eles de- 
têm a prerrogativa do jogo de búzios no terreiro). A ialorixá e o babalorixá ocupam uma posição particular cuja autoridade agrega: um tanto da legitimidade por cargos reconhecidos publicamente - em tese, pelo menos, devem ter recebido seu decá, o "diploma de pai de santo", nas palavras de baba Dary - um pouco de legitimidade tradicional, pois lembremos que deles é o orixá mais velho da casa que eles iniciaram - o que pode ser um problema em terreiros mais antigos nos quais o líder atual tem que conviver com irmãos mais velhos no santo - e esta senioridade se expressa nos termos "pai” e "mãe"; além da evidente fonte carismática de seu poder conferido pelo próprio axé de seus orixás. Se o "cargo" (que exige reconhecimento público e, portanto, o cumprimento de rituais já prescritos pela tradição, como a metáfora do "diploma" indica) permite uma boa dose de racionalização da transmissão da autoridade no candomblé, o aspecto carismático, porém, a impede no exercício cotidiano dessa mesma autoridade. Aqui encontramos o foco de muitos problemas enfrentados pelas pessoas entrevistadas.

Rosana, por exemplo, não conseguiu se adequar às exigências da hierarquia, não se acostumou a se deitar para tomar a benção a todos os mais velhos, o que fazia somente para pai Dary e nos momentos dos rituais públicos. Ela não admitia que a mandassem fazer algum serviço de limpeza no terreiro ou de preparo para as cerimônias. Seu problema não era com a atividade em si, pois ela preferia limpar os banheiros, e levava produtos por conta própria, a vê-los sujos. O problema, me parece, era receber ordens. Um dia ela se queixou comigo que não era mais uma garota para ficar se agachando o tempo todo para tratar galinhas e que mandassem "alguém mais nova”. Ora, no terreiro era ela só uma abiã, ou seja, uma "mais nova" e deveria obedecer.

Francisco se queixou do ambiente do terreiro e, na verdade, o abandonou três anos depois de ser suspenso, sem ter se confirmado para ogã. No entanto, ele afirma não ter deixado o candomblé, mas sim o terreiro. O motivo que ele alegou para sua saída foi a autori- 
dade suprema do pai de santo para decidir sobre o que pode ou não ser feito, quando e como: "Quando eles querem tudo pode, quando não, nada pode" ${ }^{69}$ Sua queixa pode ser comparada à necessidade de coerência lógica interna, mencionada por Silva (1999, p. 155, grifo do autor) ao analisar os processos de reafricanização e dessincretização que, utilizando-se da literatura acadêmica sobre o candomblé, vêm tornando a religião mais adequada " [...] ao consumo pelo mundo moderno (principalmente por uma clientela interessada também na coerência das tradições de sua religião em termos teológicos e filosóficos)."

É interessante confrontar a crítica de Francisco com a posição de alguém que ocupa exatamente o cargo de autoridade máxima. Pai Robson, que entrou para o candomblé desconhecendo os princípios básicos da religião e enfrentou muitas dificuldades de convívio no terreiro e de aprendizado das regras devido à hierarquia, comenta a respeito da forma de se aprender a religião:

Porque tudo na vida é diferente, você tem a teoria pra depois cê ter a prática. O candomblé é o inverso, ele vai na ordem inversa, você primeiro pratica, pra depois você ter o conhecimento, e o entendimento daquilo que você fez, tipo você é iniciado, você é raspado, mas você só vai entender esses atos todos, quando você começa a iniciar, tipo, sete, oito, nove anos depois. Então você vai praticar uma coisa que você já passou sem o entendimento. O que eu acho que não deveria ser. Mas ai é que tá a parte dos preceitos e fundamentos que, infelizmente, a gente não pode passar. Eaté entendo hoje porque. Porque você só pode, de repente, ter acesso a informações quando pressupõe-se que você teve um amadurecimento pra praticar aquilo que você aprendeu. [...] E fazer de maneira correta, porque se você pega essas informações antes, de maneira inconsequente, de maneira não preparada, você é capaz de começar a praticar esses atos e ao invés de ajudar, você prejudicar.

69 Vale notar que o pai de santo em questão não era do mesmo nível educacional de Francisco, o que pode ter tido alguma influência para que o problema não pudesse ser contornado. 
Há uma tensão na busca por "coerência interna” numa prática religiosa cujas regras dependem da vontade de alguém e podem ser relativizadas a depender do que exige a situação e cuja forma de transmissão do conhecimento está calcada sobre o segredo. Todavia isso não impede a formação de compromissos satisfatórios entre as expectativas pessoais e a prática coletiva, como transparece na fala de Robson. É claro que deve haver certos elementos, sobretudo rituais, quanto aos quais não se admite concessão, mas isto mesmo varia de casa para casa, e quanto às proibições e interdições, estas são na maior parte das vezes negociadas de acordo com as necessidades de cada um e com os orixás. Basta pensar nos períodos de reclusão para iniciação. Além da variação em razão das diferenças de nação, já ouvi casos - não lá em Paripe, mas em terreiros tidos como muito "tradicionais" - em que a reclusão foi reduzida a um mínimo de dias por causa dos compromissos profissionais dos envolvidos.

Para Fábio, essa maleabilidade é um problema. Em sua opinião a Federação Baiana dos Cultos Afro-Brasileiros (FEBACAB) deveria ser mais forte e atuante para poder controlar a legitimidade das práticas dos terreiros. Ele disse sentir falta de uma autoridade central, como a da Igreja Católica, que delimite e oriente os ritos e a teologia da religião como um todo. Nenhum outro entrevistado manifestou posição tão extrema, mas os casos de Fábio e Francisco apontam exatamente em que ponto se espera que a religião seja racionalizada e não o é: em sua fonte de autoridade, com o consequente poder de determinar a conduta dos seguidores.

Aliás, tanto os discursos quanto os atos das pessoas entrevistadas e acompanhadas em campo parecem marcados por esta necessidade de coerência interna, o que se traduz, por um lado, em uma racionalização moralizante da visão sobre a religião - por exemplo, atribuir aos ebós a mesma "lei do retorno" do kardecismo - e, por outro, numa tentativa de adequação estrita a gestos e comportamentos ritualmente adequados: não se chama "orixá" de "santo" nem Olorum de Deus; não existe "pecado", nem o diabo, nem inferno e 
não se participa das "marmotagens" de outros filhos de santo, isto é, de brincadeiras que consistem em imitar o transe, a dança dos outros, as atitudes dos mais velhos. É importante reiterar que esta necessidade de coerência não se concretiza num processo de racionalização efetivamente homogêneo. Embora referentes explicitamente católicos sejam normalmente evitados, outros permanecem atuantes nas explicações oferecidas nas entrevistas e comentários ouvidos em campo. Os mais evidentes consistem no uso de termos do espiritismo kardecista, como mediunidade e crescimento espiritual e na crença de alguns entrevistados em reencarnação, embora esta não possa ser atribuída necessariamente ao universo espírita. Tal ambiguidade, porém, não deve ser interpretada como um "fracasso" da busca por coerência teórica, mas apenas como uma espécie de "lembrete" de que processos reflexivos não são independentes do âmbito da prática, no qual a manutenção de ambiguidades é muito mais a norma do que a exceção. Quanto a isto é interessante relatar duas circunstâncias em que estive presente e que ilustram a natureza do conflito entre racionalização e carisma.

\section{RACIONALIZAÇÃO E MORALIDADE}

Esta busca por uma racionalização - no sentido de sistematização e coerência normativa - tem se mostrado inseparável de uma leitura moralizante da religião. Ou seja, independentemente dos postulados doutrinários exibirem uma distinção ética entre princípios absolutos de bem e mal, as pessoas encontram na religião uma orientação para suas condutas. Não estou afirmando que esta seja uma característica distintiva da classe média com nível superior de escolaridade, uma vez que é muito comum encontramos referências aos limites morais para a ação no discurso de praticamente todos os fiéis com quem mantive contato, mas apenas que, talvez, este seja um âmbito no qual possamos vir a encontrar algumas especificidades. A tão conhecida "lei do retorno" - ou "aqui se faz, aqui se paga" - não seria uma 
formulação que, mesmo escapando aos princípios absolutos, impõe limites para a vontade pessoal?

É muito complicado, é muito cheio de disse me disse, muito cheio de, de ... e outra coisa, o candomblé lhe dá uma... a crença do candomblé lhe dá isso, né? Você não gosta de alguém, 'eu não gosto de fulano, então eu vou aprontar uma com ele', assim. As pessoas fazem muito isso, no candomblé. Não, não reprime, né? Mas na verdade, o... a regulação disso, é, se dá na fé de cada um. Porque, por exemplo, é, eu posso fazer alguma coisa contra você, entendeu? Assim, mas eu, quando eu faço alguma coisa contra você, na verdade eu me esqueço que você também tem alguém, tem alguma energia com você. Você pode me devolver isso depois, cê tá entendendo? Assim, isso é, é tudo muito, as pessoas é que pensam que não é. Mas é tudo muito em pé de igualdade, não é? (Francisco)

Não seria este também o sentido da popular acusação de "fazer o mal" que é sempre dirigida a alguém que se deseja desqualificar? Lara, uma filha de santo que se encaixa em meus critérios, mas que não entrevistei formalmente, uma vez estava furiosa com uma amiga (hoje não mais amiga) que ela havia levado ao terreiro e se tornou abiã. Pegamos uma carona juntas após a sessão de caboclo e Lara reclamava o tempo todo. Acabou dizendo que poderia usar sua força espiritual contra a outra, mas que jamais faria isso, pois tal atitude "diminuiria" seu axé. Em outro momento, ao entrevistar uma filha de santo de classe baixa, esta me garantiu que poderia "jogar no buraco" quem quisesse. Fingi que não entendi e ela repetiu explicitamente que poderia fazer mal a alguém caso desejasse. Perguntei, então, se ela já havia se utilizado desse poder, o que ela negou. Eu quis saber porque e ela deu somente um muxoxo. Na verdade, ela foi a única pessoa com quem falei sobre isso que admitiu abertamente que usaria seu poder com más intenções. No geral, a questão dos ebós como malefício é tida como perigosa para o praticante ou, ao menos para alguns membros de classe média, é relativizada como no discurso de Fábio: 
Vou fazer uma comparação: quando você tá rezando, você tá fazendo um ebó, entendeu? É um preceito que você faz com a mente, com essa energia mental. Então até quando você pensa no orixá e pede alguma coisa, você tá dizendo 'tome um pouquinho dessa energia aqui' pra poder fazer com que tal coisa aconteça. Eu acredito assim. Você tira de algum lugar pra completar em outro. Você tira de um alimento pra completar em uma pessoa que tá com carência daquela energia.[...] Eu achei interessante uma vez, o... o evangélico critica muito o candomblé porque a gente faz ebó, é, faz macumba. É, faz o mal, e não sei o que, pra matar e pra separar e isso aí. Aí, um evangélico tava falando assim: 'Mas eu oro tanto, porque fulano de tal, Jesus ainda vai castigar'. Tá querendo o mal da pessoa! Não é um evangélico? Tá fazendo um ebó pro mal da pessoa. (Fábio)

Evidentemente, a ideia de que os rituais do candomblé podem ser utilizados para qualquer finalidade - e que corresponde ao medo que os não adeptos dizem ter da religião - confere poder aos seus praticantes. Entretanto, é exatamente esse poder que é negado pelas pessoas que entrevistei ou remetido a qualquer uma das religiões, pois o que conta é a "intenção" individual. Pedro contou que suas tias, e mesmo sua avó, haviam tido algum contato com o candomblé como "clientes", mas que tiveram uma péssima experiência e ficaram amedrontadas. Quando pedi mais explicações, ele disse apenas:

Elas quiseram usar a energia do candomblé para [...] a energia, quiseram usar energias negativas. Então, eu acho que existe uma lei universal, independente de religião, que quando você deseja algo de ruim pra uma pessoa aquilo volta sete vezes pra você. Isso é a mesma coisa pra energias positivas.

O babalorixá Dary enfatiza com frequência os três "dogmas" da religião: o segredo, o preceito e o respeito. O segredo, segundo ele, é necessário para que pessoas não preparadas não tenham acesso aos fundamentos do candomblé, o que poderia trazer prejuízos tanto para a religião - devido ao descrédito, ao desprestígio causado por 
ações desastrosas - quanto para os indivíduos envolvidos, que poderiam ser lesados por aqueles que, mal intencionados, detivessem esse conhecimento poderoso. O preceito refere-se não apenas às normas e exigências de comportamento, muito frequentes no candomblé, mas também envolve questões rituais bastante complexas, protegidas pelo segredo. Já o respeito deve ser dirigido tanto às divindades - toda e qualquer uma - quanto aos nossos semelhantes. É interessante notar que o babalorixá não aceita muito bem a ideia de "castigo" do orixá, preferindo expressar-se nos termos de "afastamento" deste, o que deixa seu filho desprotegido e suscetível a diversas contrariedades. Ele próprio tem uma história neste sentido para contar, e quando o faz enfatiza mais sua própria ignorância do que a represália do orixá. Pai Dary costuma dizer que o candomblé é a "religião mais racional" que há, pois não deixa coisa alguma sem explicação, e é ele um dos que enfatizam a necessidade de se "ensinar", educar os filhos de santo que devem estar informados a respeito do sentido dos atos que praticam e não apenas reproduzi-los. Para este babalorixá, a forma "antiga" de aprendizado no candomblé - ver e ouvir sem perguntar - nada mais é do que uma estratégia para a manutenção do poder nas mãos de um grupo restrito.

Em seu processo de iniciação ele enfatiza seu desconhecimento da forma correta de lidar com a divindade, tentando obter do orixá um benefício mundano - sua transferência para Salvador - em troca da feitura. Ao fim ele comenta: "Então uma coisa que a gente aprende, que o orixá lhe atende, o orixá lhe protege, mas só que o orixá não faz trocas comerciais”. Para ele a iniciação tem o caráter profundo de morte e renascimento para uma nova vida e condiz perfeitamente com a concepção já registrada na literatura socioantropológica sobre o candomblé:

Depois que a gente entra no candomblé, que a gente nasce, porque, a iniciação é um renascimento. É uma morte da vida anterior e um nascimento, tanto que você recebe um nome novo, em iorubá. Então, você é batizado, você reaprende a viver, reaprende a conhecer as coisas. Faz parte 
do ato de iniciação. Então, the é mostrado a rua, o tempo, o que é uma cadeira, onde você senta, como você come, tudo isso é re-ensinado, né? Simbolicamente, pra significar um renascimento [...] Inclusive o ato de raspar a cabeça significa isso, né? É a morte pra renascer. Você joga fora tudo o que não prestava pra uma nova vida.

É possível perceber tanto uma tentativa de racionalização teórica quanto uma moralização da conduta dos próprios orixás, em sua maneira de ver a religião: eles nunca farão algo de mal a seus filhos, o comportamento inadequado destes é que pode resultar em seu próprio prejuízo. Mas isto implica numa contraparte: os orixás se tornam mais incompreensíveis uma vez que se afastam do padrão humano de comportamento, seus desígnios tornam-se mais misteriosos. A citação presente na abertura deste texto é uma fala do outro babalorixá, pai Robson, que ressalta o quando foi difícil, para ele próprio, compreender os significados de sua iniciação, hoje expressos em termos de uma "mudança de valores", de “orientação" da própria vida, e de poder auxiliar aos outros no mesmo sentido. Embora estes dois casos sejam de sacerdotes, esse tipo de discurso não se limita a sua categoria. Helena enfatiza que o candomblé, para ela, abriu uma possibilidade de atuação em benefício do próximo, que a sociedade de hoje castra, e destaca o agir como oposição ao "falso moralismo" de outras religiões (principalmente as grandes “religiões éticas”):

Eu acho que tem um, uma porção de aspectos que me interessa mais em relação às outras religiões. Que eu acho que as outras, realmente, 'pregam', do ponto de vista do Decálogo, da escrita e tudo o mais, e na verdade pouco praticam, né? Eu pelo menos vejo. Entre as pessoas que, que frequentam, quer dizer, essa coisa da pessoa que vai pra igreja, que faz isso, que faz aquilo e que, na verdade, maltrata a quem trabalha em casa, maltrata o não sei o que, não é generosa com não sei quem, só pensa em ganância, só pensa nisso, só pensa naquilo, só pensa em corrupção. Então... não vejo muita, lógica, nisso. [...] Que as outras acabam tendo, aqueles rituais. Não, cê tem que acender vela, cê tem que 
ler a Bíblia não sei quantos dias, cê tem que decorar não sei o que lá e tal, mas que isso é uma coisa, coisas, rituais apenas, né? Eu acho que não, eu acho que com o candomblé você tem uma atenção para com você, pra com as outras pessoas, pra com a natureza, pra com o seu cotidiano, contínua, processual, é uma coisa processual. [ênfase na entonação]

A meu ver, nesta reelaboração religiosa não é possível distinguir facilmente a leitura racionalizante da moralizante, ou seja, trata-se de um só processo de apropriação do discurso religioso, que ao mesmo tempo em que o sistematiza, busca sua coerência interna e aproxima-o das exigências morais dos adeptos. Lembremos que para estas pessoas o que as distingue das camadas mais baixas é a “educação" e, como vimos, isto não se refere somente à "cultura" e escolaridade, mas alcança à moral manifestada nas condutas. Assim, temos um foco de desconforto que deve ser tolerado no cotidiano do terreiro. A experiência individual do transe não cria um problema quanto às expectativas de racionalização religiosa. Já a fonte de autoridade sim, principalmente a pouca possibilidade de racionalização da condução da vida cotidiana com base nessa autoridade e a falta de sistematização da moralidade esperada da religião que não encontra meios de se impor ao grupo como um todo. Isto surge como problemático para as pessoas entrevistadas e, deste ponto de vista, há uma apropriação de classe média da religião.

\section{CONCLUSÕES PARCIAIS: CANDOMBLÉ E INDIVIDUALIDADE}

A entrada no candomblé distingue, e por vezes opõe, as pessoas entrevistadas aos demais membros de suas famílias e de sua classe social ampla e heterogênea, de modo semelhante ao que igrejas evangélicas atuais operam como "solvente" das lealdades anteriores à conversão. (PIERUCCI, 2006) Por esse ângulo vemos que especialmente para estas pessoas o ingresso no candomblé apresenta um elemento de individuação. Como todas as famílias vinham de um universo ca- 
tólico e/ou kardecista, com algum contato com a umbanda, pode-se imaginar que qualquer outra religião, como as orientais, teria $\mathrm{o}$ mesmo efeito - e no caso especial de Ernesto, o médico de família comunista, qualquer forma de religiosidade poderia vir a dar na mesma, já que seus familiares são ateus convictos. No entanto, é preciso considerar o forte estigma que ainda pesa sobre o candomblé, mesmo na Salvador do século XXI. Para muitas pessoas de classe média esta religião ainda é "superstição de gente ignorante" ou "feitiçaria", e há pessoas que têm medo sem jamais ter mantido qualquer contanto maior do que ver um grande ebó numa avenida soteropolitana..$^{70}$ Assim, anunciar em casa a iminente iniciação no candomblé não tem o mesmo impacto que comunicar uma conversão ao budismo, por exemplo. Já a entrada para a Igreja Universal do Reino de Deus talvez despertasse rejeição semelhante.

Este ponto ficou claro nas entrevistas. Paulo, como vimos, rompeu com a família paterna aos 14 anos pela religião. Pedro, quando finalmente contou a sua mãe que havia se confirmado, enfrentou não apenas as reclamações como, sobretudo, o receio de que ele viesse a ter que abrir um terreiro (e Pedro é ogã). Fábio e Ana ainda não conseguiram que seus familiares fossem às suas obrigações, exceto a mãe dela. Marta tem uma irmã que passa por problemas espirituais, mas que se recusa a procurar um terreiro devido aos preconceitos que nutre, segundo a entrevistada. Em muitos casos os familiares passaram a uma melhor aceitação, principalmente, por verem como estas pessoas têm trajetórias ordenadas e "normais", embora o pai de Ernesto nunca tenha aceitado conhecer o terreiro e ainda faça brincadeiras acerca da religião do filho. Pelo candomblé estas pessoas se distinguem de seu meio social de origem, ao passo que por causa desta origem distinguem-se da maior parte dos adeptos. Enfrentam

70 Dois exemplos pessoais rápidos: mais de um conhecido me perguntou se eu não tinha medo de pesquisar o candomblé, inclusive colegas da Universidade Federal da Bahia; certa vez abandonei uma consulta após discutir com o médico que insistia que era um contrassenso eu dizer que eu estudava Sociologia da "Religião" e pesquisar uma "superstição". 
abertamente as críticas e preconceitos da parte de familiares, amigos e colegas, declaram sua opção religiosa quando solicitados a fazê-lo, como ao responder o Censo do IBGE, por exemplo, mas ao mesmo tempo criticam o comportamento de outros membros do terreiro que, muitas vezes, é sentido como inadequado e ofensivo.

A menor ênfase na religião como esfera central de interação social - sendo mais um dos meios que se frequenta - coaduna-se com a valorização da ideia de "busca pessoal". Hervieu-Léger salienta a correlação entre o fenômeno da religião como "busca pessoal” na modernidade e o problema da transmissão de tradições culturais de uma geração a outra. Na sociedade moderna as "crises de transmissão" têm obrigado as instâncias de socialização (e a religião é uma delas) a se adequar a novas estratégias de transmissão que logrem ultrapassar as verdadeiras "fraturas culturais" intergeracionais que vêm surgindo. Neste contexto é que a transmissão religiosa tem seu caráter institucional cada vez mais enfraquecido e ganha ênfase a trajetória individual. Essa valorização da religião por opção própria, da busca religiosa pessoal e "autêntica”, combina com o que poderíamos chamar de modernidade psicológica, ou seja, com a ideia de que cada um é um indivíduo que deve se esforçar para manter uma identidade pessoal muito mais forte do que qualquer identidade imposta por uma fonte externa de autoridade, da qual não devemos mais nos conformar. (HERVIEU-LÉGER, 1998, p. 216)

Esta análise pode ser aplicada ao presente caso, no qual a religião "escolhida" é justamente uma que permite a singularização da posição religiosa da pessoa, através de suas relações específicas com divindades e cargos, enquanto oferece mais de uma forma de inserção no grupo enquanto instituição. Mais uma vez, proponho que esta possibilidade de combinações variadas de experiências e posições dentro do grupo religioso pode muito bem constituir um forte atrativo para indivíduos de classe média altamente escolarizados. Esta atração, porém, se dá através de uma apropriação da religião que 
se ressente da impossibilidade de um alto grau de racionalização da autoridade e da conduta da vida, ao passo que impõe certas marcas morais à prática religiosa. Segundo Bourdieu (2003) são exatamente as formas de apropriação de "bens" culturais que expressam um estilo de vida. Mesmo o produto mais técnico é apropriado de acordo com valorações e posicionamentos no espaço social. A religião, porém, não é um "produto" cultural como outro qualquer, pois, como já foi dito, envolve a admissão de uma categoria especial de agentes. Em outras palavras, podemos afirmar que a entrada em certo mundo religioso oferece elementos para o estilo de vida em que é apropriada.

Neste capítulo foi destacado como uma situação de classe favorece determinada apropriação de uma religião. Podemos acentuar as reorientações que esta religião oferecer para a condução da vida cotidiana, mas antes é preciso analisar detidamente em que sentido e em que medida é possível se afirmar que as características acima exploradas permitem e operam a construção de identidades pessoais e, sobretudo, de que forma as trajetórias religiosas analisadas são compreendidas por aqueles que as viveram. É necessário explicitar o que significa "autoidentidade" e suas correlações com as experiências que procurei classificar nestes dois primeiros capítulos. 